\title{
Uji Perbandingan Aktivitas Penyembuhan Luka Sayat Fraksi n-Heksan, Metanol, dan Ekstrak Daun Talas (Colocasia esculenta (L.) Schott)
}

\author{
Dita Maharani ${ }^{1}$, W Wirasti ${ }^{2 *}{ }$ SSlamet $^{3}$, Urmatul Waznah ${ }^{4}$ \\ 1,2,3,4Program Studi Sarjana Farmasi, Universitas Muhammadiyah Pekajangan Pekalongan, \\ Indonesia \\ *email: wirasti.kharis@gmail.com
}

\begin{abstract}
Talas or taro leaf contains active compounds in the form of flavonoids and saponins that can accelerate the process of epidermal tissue re-epitalization and infiltration of inflammatory cells in the wound area. The purpose of this study was to compare the healing activities of the n-hexane fraction, methanol fraction, and taro leaf extract in New Zealand rabbits. The extraction method using maceration, the fractionation method used liquid-liquid partition with a separating funnel and the treatment method on test animals used was the application of the n-hexane fraction, methanol fraction, and taro leaf extract on open wounds of New Zealand rabbits with positive control and negative control. The data obtained is in the form of the value of open wound narrowing on the rabbit's back. The result of the data were analyzed by ANOVA (Analysis Of Variant) followed by the LSD (Least Significant Different) test to see which treatment gave different effect in each group. The results of the research or testing for 14 days showed that the extract, $\mathrm{n}$-hexane fraction, and methanol fraction had wound healing activity on the rabbit back with statistical data showing significant differences between treatment groups. The extract had the most optimal wound healing activity compared to other treatment groups.
\end{abstract}

Keywords: talas leaf, extract, fraction, wound

\begin{abstract}
Abstrak
Daun talas mengandung senyawa aktif berupa flavonoid dan saponin yang mampu mempercepat proses reepitalisasi jaringan epidermis dan infiltrasi sel-sel radang pada daerah luka. Tujuan dari penelitian ini yaitu mengetahui perbandingan aktivitas penyembuhan luka terbuka fraksi n-heksan, fraksi metanol, dan ekstrak daun talas pada kelinci New Zealand. Metode ekstraksi menggunakan maserasi, metode fraksinasi menggunakan partisi cair-cair dengan corong pisah dan metode perlakuan pada hewan uji yang digunakan adalah pengolesan fraksi n-heksan, fraksi metanol, dan ekstrak daun talas pada luka terbuka kelinci New Zealand dengan kontrol positif dan kontrol negatif. Data yang didapatkan adalah berupa nilai penyempitan luka terbuka pada punggung kelinci. Hasil data dianalisis dengan ANOVA(Analysis Of Variant) yang dilanjutkan dengan uji LSD (Least Significant Different) untuk melihat perlakuan mana yang memberikan efek yang berbeda ditiap kelompok. Hasil penelitian atau pengujian selama 14 hari menunjukkan bahwa ekstrak, fraksi metanol, dan fraksi n-heksan mempunyai aktivitas penyembuhan luka pada punggung kelinci dengan data statistik yang menunjukkan adanya perbedaan signifikan antar kelompok perlakuan. Ekstrak mempunyai aktivitas daya sembuh luka yang paling optimal dibandingkan dengan kelompok perlakuan lain.
\end{abstract}

Kata kunci : daun talas; ekstrak; fraksi; luka

\section{Pendahuluan}

Luka adalah salah satu permasalah medis yang sering ditemui yang dapat terjadi kapan dan dimana saja dan terkadang tidak disadari bahayanya. Luka merupakan terputusnya kontinuitas jaringan karena cedera atau pembedahan (Kartika,2015). Cedera dapat disebabkan seperti trauma benda tajam maupun tumpul, gigitan hewan, 


\section{Prosiding Seminar Nasional Kesehatan 2021 Lembaga Penelitian dan Pengabdian Masyarakat Universitas Muhammadiyah Pekajangan Pekalongan}

zat kimia, ledakan, sengatan listrik, terjatuh, dan lain sebagainya. Obat luka yang biasa digunakan dan dikenal luas oleh masyarakat adalah povidone iodine. Povidone iodine merupakan agen antimikroba yang efektif sebagai desinfeksi dan pembersih kulit dalam penatalaksanaan luka traumatik (Morison, 2003).

Luka dapat diklasifikasikan berdasarkan mekanisme terjadinya luka, berdasarkan kedalaman dan luas luka yaitu stadium I, II, III, dan IV. Proses penyembuhan luka terjadi dalam beberapa tahap yang terdiri dari fase inflamasi yang menimbulkan reaksi kemerahan, edema, hangat, dan nyeri lokal. Fase proliferasi, yaitu fase regenerasi jaringan baru yang mulai menutup luka. Dan fase maturasi yaitu jaringan parut kolagen yang terus mengalami remodeling untuk mencapai keadaan jaringan seperti semula (Maryunani, 2015).

Pemberian obat luka secara tradisional biasa dilakukan secara empiris dengan memanfaatkan sumber daya alam seperti tumbuh-tumbuhan. Salah satu tumbuhan yang dapat dimanfaatkan sebagai obat luka adalah talas (Colocasia esculenta (L.) Schott) yang telah dikenal oleh masyarakat untuk menyembuhkan luka ringan, luka bakar hingga pendarahan (Sangtam, dkk. 2012).

Senyawa metabolit sekunder yang berperan dalam membantu proses penyembuhan luka terdapat dalam tanaman talas.Flavonoid dan fenolik sebagai antibakteri pada berbagai bakteri patogen dan berperan dalam proses regenerasi jaringan kulit pada luka sehingga luka dapat dengan cepat tertutup. Saponin merupakan komponen bioaktif yang berperan dalam pembentukan kolagen. Tanin berperan dalam pengkoagulasian darah dan sebagai antiinflamasi (Muralidhar, dkk. 2013).Berdasarkan penjelasan tersebut, penulis ingin mengetahui sifat kepolaran dari senyawa yang terkandung dalam daun talas dengan metode fraksinasi untuk kemudian dilakukan uji terhadap penyembuhan luka terbuka. Maka tujuan dari penelitian ini yaitu untuk mengetahui perbandingan aktivitas penyembuhan luka terbuka dari fraksi nheksan, fraksi metanol, dan ekstrak daun talas pada kelinci New Zealand.

\section{Metode}

Penelitian ini merupakan studi eksperimental dengan menggunakan rancangan penelitian post test only control group design dimana pengukuran hanya dilakukan setelah perlakuan selesai.

\section{Alat}

Rotary evaporator (Heidolph), bejana (wadah kaca), timbangan analitik (OHAUS PA224), kertas saring (Whatmann), beaker glass (Pyrex), ayakan nomor 40, batang pengaduk, erlenmeyer (Pyrex), cawan porselein, oven (Memmert), corong pisah (Pyrex), tabung reaksi (Pyrex), rak tabung reaksi, gelas ukur (Pyrex), pipet tetes (Pyrex), kaca arloji, kompor listrik, penangas air, plat tetes, moisture analyzer (MB 25), dan pisau bedah.

\section{Bahan}

Simplisia daun talas (Colocasia esculenta (L.) Schott), etanol 96\%, n-heksan, metanol, $\mathrm{H} 2 \mathrm{SO} 4$, reagen Wagner, reagen Dragendroff, reagen Mayer, $\mathrm{FeCl} 3$, serbuk 


\section{Prosiding Seminar Nasional Kesehatan Lembaga Penelitian dan Pengabdian Masyarakat Universitas Muhammadiyah Pekajangan Pekalongan}

$\mathrm{Mg}, \mathrm{HCl}$, asam asetat glasial, kloroform, ammonia, aquadest, betadine, etanol $70 \%$, dan cream anestesi.

\section{Penyiapan Simplisia}

Daun talas (Colocasia esculenta (L.)Schott) $10 \mathrm{~kg}$ yang telah dikumpulkan, disortasi basah, kemudian dicuci dengan air bersih mengalir.Selanjutnya daun dikeringkan dibawah sinar matahari secara tidak langsung dengan ditutup kain hitam.Simplisia daun talas yang sudah kering disortasi kering, lalu dihaluskan, serbuk diayak dengan nomor 40 .

\section{Pembuatan Ekstrak}

Serbuk daun talas sebanyak $1 \mathrm{~kg}$ dimaserasi dengan etanol 96\% sebanyak 6000 $\mathrm{mL}$ selama 72 jam dan diaduk setiap harinya selama 1 jam kemudian diremaserasi selama 48 jam. Setelah disaring, filtrat dievaporasi dengan menggunakan rotary evaporator.Hasil evaporasi dimasukan ke dalam oven pada suhu $60^{\circ} \mathrm{C}$ hingga diperoleh ekstrak kental.

\section{Pembuatan Fraksi}

Sebanyak $100 \mathrm{~g}$ ekstrak daun talas dilarutkan dalam $100 \mathrm{~mL}$ n-heksan dan $100 \mathrm{~mL}$ metanol ke dalam corong pisah, kemudian dikocok dan didiamkan hingga membentuk dua lapisan. Selanjutnya dipisahkan antara residu, fraksi n-heksan, dan fraksi metanol.Kemudian masing-masing partisi diuapkan menggunakan oven sampai didapatkan fraksi kental n-heksan dan fraksi kental metanol.

\section{Pengujian Fitokimia}

\section{Uji Alkaloid}

Masing-masing dari fraksi n-heksan, fraksi metanol, dan ekstrak daun talas diambil sebanyak $1 \mathrm{~g}$ lalu dimasukan kedalam tabung reaksi, ditambahkan $2 \mathrm{~mL}$ kloroform dan $2,5 \mathrm{~mL}$ ammonia $10 \%$, lalu ditambahkan 10 tetes asam sulfat $2 \mathrm{M}$ untuk memperjelas pemisahan terbentuknya 2 fase yang berbeda. Bagian atas dari fase yang terbentuk diambil dan ditambahkan reagen mayer. Keberadaan alkaloid dalam sampel ditandai dengan terbentuknya endapan merah (Harborne, 1987).

\section{Uji Flavonoid}

Masing-masing dari fraksi n-heksan, fraksi metanol, dan ekstrak daun talas diambil sebanyak $1 \mathrm{~g}$, dimasukan kedalam tabung reaksi, ditambahkan serbuk magnesium secukupnya dan 10 tetes asam klorida pekat. Keberadaan flavonoid ditandai dengan terbentuknya warna hitam kemerahan pada larutan (Harborne, 1987).

\section{Uji Tanin}

Masing-masing dari fraksi n-heksan, fraksi metanol, dan ekstrak daun talas diambil sebanyak $1 \mathrm{~g}$, ditambahkan dengan air panas, kemudian di tetesi menggunakan besi (III) klorida, keberadaan tanin dalam sampel di tandai dengan timbulnya warna hijau kehitaman (Harborne, 1987). 


\section{Prosiding Seminar Nasional Kesehatan 2021 \\ Lembaga Penelitian dan Pengabdian Masyarakat Universitas Muhammadiyah Pekajangan Pekalongan}

\section{Uji Saponin}

Masing-masing dari fraksi n-heksan, fraksi metanol, dan ekstrak daun talas diambil sebanyak $1 \mathrm{~g}$, ditambahkan akuades, dikocok kuat selama kurang lebih 1 menit. Selanjutnya didiamkan 10 menit dan diamati busa yang terbentuk.Keberadaan senyawa saponin dalam sampel ditandai dengan terbentuknya buih yang stabil selama 10 menit dengan tinggi $3 \mathrm{~cm}$ (Harborne, 1987).

\section{Uji Steroid dan Terpenoid}

Masing-masing dari fraksi n-heksan, fraksi metanol, dan ekstrak daun talas diambil sebanyak $1 \mathrm{~g}$, ditambahkan kloroform 20 tetes, lalu dikocok.Disaring, filtrat ditambahkan asetat anhidrat dan asam sulfat pekat sebanyak 2 tetes. Steroid memberikan warna biru atau hijau, sedangkan terpenoid memberikan warna merah atau ungu (Harborne, 1987).

\section{Pembuatan Sampel Pengujian}

Variabel yang digunakan adalah kontrol negatif dimana luka yang dibuat pada hewan uji tidak mendapat perlakuan apapun. Kemudian untuk kontrol positif menggunakan betadin cair dengan pemakaian $1 \mathrm{x}$ sehari sebanyak 0,2 g untuk setiap luka. Sedangkan untuk pengujiannya menggunakan fraksi n-heksan 0,3 g, fraksi methanol $0,2 \mathrm{~g}$, dan ekstrak daun talas $0,2 \mathrm{~g}$ diberikan pada luka $1 \mathrm{x}$ sehari.

\section{Proses Pembuatan Luka}

Pembuatan luka dilakukan pada bagian punggung kelinci.Sebelum kelinci digunakan untuk percobaan, kelinci diadaptasi selama 1 minggu yang ditempatkan dalam kandang yang bersih dan diberi makan dan minuman yang sesuai. Kemudian, dilakukan proses pembuatan luka, pertama dilakukan proses pencukuran bulu di sekitar punggung dengan ukuran $4 \mathrm{~cm}^{2}$ dan kulit didesinfeksi dengan alkohol $70 \%$. Selanjutnya pemberian anestesi dan dilanjutkan dengan pembuatan luka menggunakan pisau bedah yang telah disterilkan dengan alkohol $70 \%$. Pembuatan luka pada kulit daerah punggung sepanjang $2 \mathrm{~cm}$ dengan kedalaman mencapai lapisan epidermis.Jenis luka ini termasuk ke dalam luka superfisial (Non-Blanching Erithema), yaitu luka yang terjadi pada lapisan epidermis kulit (Maryunani, 2015).

\section{Tahap pengujian}

Hewan uji kelinci jenis New Zealand sebanyak 15 ekor dengan berat badan 1,5-2 $\mathrm{kg}$ dan berumur 5-6 bulan, dibagi kedalam 5 kelompok yang masing-masing kelompok terdiri dari 3 ekor yang diberikan 5 perlakuan yaitu : perlakuan A; luka tanpa perlakuan (kontrol negatif), perlakuan $\mathrm{B}$; luka diberi $\pm 0,3 \mathrm{~g}$ fraksi $\mathrm{n}$-heksan, perlakuan $\mathrm{C}$; luka diberi $\pm 0,2 \mathrm{~g}$ fraksi metanol, perlakuan $\mathrm{D}$; luka diberi $\pm 0,2 \mathrm{~g}$ ekstrak daun talas, perlakuan $\mathrm{E}$; luka diberi $\pm 0,2 \mathrm{~g}$ obat betadine cair (kontrol positif). Dilakukan pengamatan dan pengukuran penyempitan luka yang dilakukan setiap hari selama 14 hari serta membandingkannya dengan kontrol. 


\section{Prosiding Seminar Nasional Kesehatan Lembaga Penelitian dan Pengabdian Masyarakat Universitas Muhammadiyah Pekajangan Pekalongan}

\section{Analisis Data}

Untuk mengetahui ada tidaknya aktivitas penyembuhan luka berdasarkan perbandingan pemberian fraksi n-heksan, fraksi metanol, dan ekstrak daun talas maka data dianalisis dengan ANOVA (Analysis Of Variant) dengan a 0,05 atau 5\%. Jika ada perbedaan yang signifikan, dilanjutkan dengan uji LSD (Least Significant Different) melihat perlakuan mana yang memberikan efek yang berbeda.

\section{Hasil dan Pembahasan}

\section{Hasil}

Tabel 3.1 Hasil Skrining Fitokimia Daun Talas

\begin{tabular}{|c|c|c|c|c|c|c|}
\hline \multirow[t]{2}{*}{ Sampel } & \multicolumn{3}{|c|}{ Pemeriksaan } & \multirow[b]{2}{*}{ Saponin } & \multirow[b]{2}{*}{ Steroid } & \multirow[b]{2}{*}{ Terpenoid } \\
\hline & Alkaloid & Flavonoid & Tanin & & & \\
\hline Ekstrak & +++ & ++ & ++ & +++ & ++ & - \\
\hline $\begin{array}{l}\text { Fraksi } \\
\text { n-heksan }\end{array}$ & - & - & & - & +++ & - \\
\hline $\begin{array}{l}\text { Fraksi } \\
\text { Metanol }\end{array}$ & +++ & +++ & ++ & +++ & - & - \\
\hline
\end{tabular}

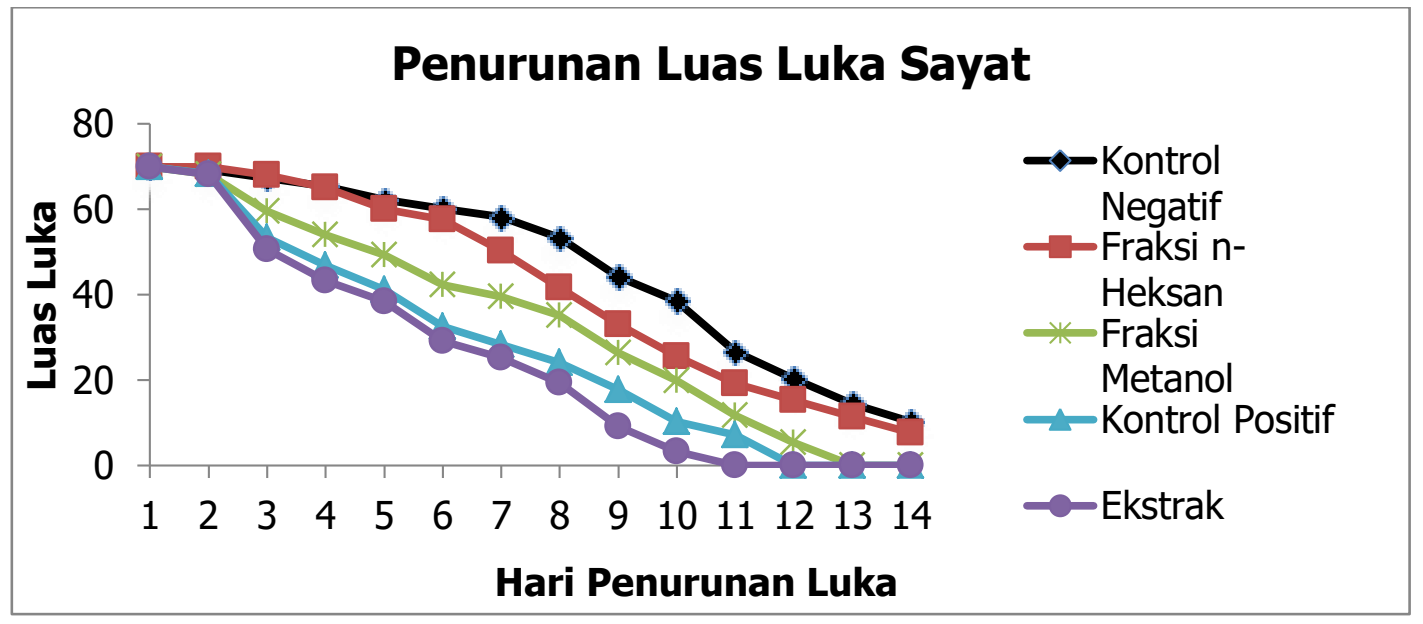

Grafik 3.1 Grafik Rata-Rata Penurunan Luas Luka 


\section{Prosiding Seminar Nasional Kesehatan 2021 \\ Lembaga Penelitian dan Pengabdian Masyarakat Universitas Muhammadiyah Pekajangan Pekalongan}

Tabel 3.2 Hasil Pengolahan Data Menggunakan One Way ANOVA

ANOVA

\begin{tabular}{lr|r|r|r|r}
\multicolumn{2}{l}{$\begin{array}{c}\text { Kesembuhan of } \\
\text { Squares }\end{array}$} & Df & Mean Square & \multicolumn{1}{l}{ F } & \multicolumn{1}{c}{ Sig. } \\
\hline $\begin{array}{l}\text { Setween } \\
\text { Groups }\end{array}$ & 5836,281 & 4 & 1459,070 & 2,612 &, 043 \\
\hline $\begin{array}{l}\text { Within } \\
\text { Groups }\end{array}$ & 36310,538 & 65 & 558,624 & & \\
\hline Total & 42146,819 & 69 & & & \\
\hline
\end{tabular}

Tabel 3.2 Hasil Skrining Fitokimia Daun Talas

\begin{tabular}{llcccc}
\hline Perlakuan & $\begin{array}{l}\text { Kontrol } \\
\text { negatif }\end{array}$ & $\begin{array}{l}\text { Fraksi } \\
\text { heksan }\end{array}$ & $\begin{array}{l}\text { Fraksi } \\
\text { metanol }\end{array}$ & Ekstrak & $\begin{array}{l}\text { Kontrol } \\
\text { positif }\end{array}$ \\
\hline $\begin{array}{l}\text { Kontrol } \\
\text { negatif }\end{array}$ & & & & 0,006 & 0,042 \\
$\begin{array}{l}\text { Fraksi } \mathbf{n}- \\
\text { heksan }\end{array}$ & & & 0,024 & \\
$\begin{array}{l}\text { Fraksi } \\
\text { metanol }\end{array}$ & & & & \\
Ekstrak & 0,006 & 0,024 & & \\
Kontrol & 0,042 & & & \\
positif & & & & \\
\hline
\end{tabular}

\section{Pembahasan}

Grafik 3.1 didapatkan hasil bahwa untuk setiap perlakuan penyembuhan luka sayat yang dilihat dari penurunan luas permukaan luka mempunyai aktivitas penuruan luas permukaan yang berbeda-beda.Dapat dilihat dari 5 kelompok yang terdiri dari ekstrak, fraksi n-heksan, fraksi metanol, kontrol positif dan kontrol negatif berbeda disetiap harinya.Apabila dilihat dari perbandingan antara kelompok perlakuan dengan hasil penurunan luas luka yaitu rata-rata penurunan luas luka terjadi pada hari ke 3.Dari hasil tersebut untuk kelompok perlakuan ekstrak menunjukan penurunan lebih cepat bila dibandingkan kelompok fraksi n-heksan, fraksi metanol, kontrol positif dan kontrol negatif.

Penelitian ini selain meninjau dari parameter penurunan luas permukaan luka selama 14 hari juga dilihat dari hari kesembuhan luka untuk setiap kelompok mulai dari perlakuan dengan ekstrak, fraksi n-heksan, fraksi metanol, kontrol positif dengan obat povidone iodine dan kontrol negatif yang tidak mendapat perlakuan apapun. Pada tiap perlakuan luka sayat mencapai hari kesembuhan yang berbeda-beda. Urutan hari kesembuhan paling cepat terjadi pada ekstrak yaitu mencapai kesembuhan luka pada hari ke 11, kesembuhan pada kontrol positif terjadi pada hari ke 12, untuk fraksi metanol menunjukan kesembuhan pada hari ke 13, sedangkan perlakuan fraksi n- 


\section{Prosiding Seminar Nasional Kesehatan 2021 Lembaga Penelitian dan Pengabdian Masyarakat Universitas Muhammadiyah Pekajangan Pekalongan}

heksan dan untuk kontrol negatif pada hari ke 14 belum mengalami kesembuhan $100 \%$.

Perbedaan kesembuhan luka tiap kelompok dipengaruhi oleh kandungan senyawa metabolit sekunder yang berbeda tergantung dari kepolaran yang sesuai dengan pelarutnya.Pada ekstrak terdapat metabolit sekunder yang lengkap seperti pada tabel 3.1 hasil skrining, sehingga mendukung penyembuhan luka lebih cepat dari kelompok perlakuan lain. Hasil skrining ekstrak daun talas tersebut sesuai dengan penelitian sebelumnya yang dilakukan oleh Noorritha (2015) yaitu pada ekstrak daun talas mengandung alkaloid, flavonoid, tanin, saponin, dan steroid. Pada fraksi n-heksan hanya mengandung 1 metabolit sekunder yaitu steroid yang berkhasiat sebagai antiinflamasi, dan pada fraksi metanol terdapat 4 kandungan metabolit sekunder. Senyawa yang berperan dalam penyembuhan luka diantaranya yaitu flavonoid dan fenolik yang berperan dalam proses epitelisasi dalam menstimulasi proses regenerasi jaringan kulit pada luka sehingga luka dapat dengan cepat tertutup dengan kulit baru. Saponin berperan dalam pembentukan kolagen.Sedangkan tanin berperan dalam pengkoagulasian darah dan sebagai antiinflamasi (Muralidhar, dkk. 2013). Penelitian yang dilakukan oleh Ahmad dkk (2017) dan Dalaratmi 2017 menyatakan bahwa daun talas mengandung senyawa yang berperan sebaga antibakteri, yaitu senyawa flavonoid dan saponin. Dengan demikian, luka yang diberikan ekstrak maupun fraksi dengan kandungan tersebut dapat meminimalisir terjadinya infeksi.

\section{Kesimpulan}

Dari hasil penelitian yang telah dilakukan dapat disimpulkan bahwa ekstrak, fraksi n-heksan, dan fraksi metanol daun talas mempunyai aktivitas daya sembuh luka sayat pada punggung kelinci.Urutan kelompok perlakuan yang paling efektif terhadap daya sembuh luka sayat pada punggung kelinci yaitu ekstrak, kontrol positif, fraksi metanol, fraksi n-heksan, dan kontrol negatif.

\section{Referensi}

[1] Pulungan,Ahmad S.S., Brata,Wasis W.W., 2017, Aktivitas Antibakteri Ekstrak Etanol Daun Talas Terhadap Bakteri Patogen, Jurnal Saintika., Volume 17(1): 76 $-79$

[2] Alcantara RM, WA Hurtada, EI Dizon. 2013. The Nutritional Valueand Phytochemical Components of Taro (Colocasia esculenta (L.) Schoot) Powder and its Selected Processed Foods. Journal of Nutrition Food Science.3(3). 1-7

[3] Chakraborty, P., Deb, P., Chakraborty, S., Chatterjee, P., and Abraham,J. 2015.Cytotoxicity and Antimicrobial Activity of Colocasia esculenta. Journal of CheKHMal and Pharmaceutical Research. 7(12): 627-635.

[4] Dalaratmi., 2018, Efek Sinergisme Aktivitas Antibakteri Fraksi Etil Asetat Daun Talas (Colocasia Esculenta L. Schott) dan Amoksisilin Terhadap BakteriMethicillinResistant Staphylococcus aureus (MRSA), Skripsi, Fakultas Farmasi, Universitas Hasanuddin, Makassar

[5] Dwivedi,P., Dwivedi,J., Patel,D., Desai,S., and Meshram,D. 2016. Phyto cheKHMal Analysis and In Vitro Urolithiatic Activity of Colocasia esculenta leaves. Journal of Medicinal Plants Studies.4(3): 18-22. 


\section{Prosiding Seminar Nasional Kesehatan 2021 Lembaga Penelitian dan Pengabdian Masyarakat Universitas Muhammadiyah Pekajangan Pekalongan}

[6] Harborne, J. B. 1987. Metode Fitokimia Penuntun Cara Modern Menganalisis Tumbuhan. ITB Press:Bandung.

[7] Herwin., dkk. 2016. Aktivitas Antibakteri Ekstrak Etanol Daun Talas Ketan (Colocasia esculenta) Terhadap Bakteri Saphylococcus aureus Dan Salmonella thypi Secara Difusi Agar. As-Syifaa Vol 08 (01) : Hal. 69-75, Juli 2016.

[8] Karimi E, HZE Jaafar, S Ahmad. 2011. Phytochemical Analysis and Antimicrobial Activities of Methanolic Extract of Leaf, Stem and Root from Different Varieties of Labisa pumila Benth. Molecules 16. 4438-4450.

[9] Kartika, R. W. (2015). Perawatan Luka Kronis dengan Modern Dressing. CDK-230, pp. 546-550

[10] Maryunani, A. (2015). Perawatan luka modern (Modern Woundcare). Jakarta : IN MEDIA

[11] Morison, J. 2003. Manajemen Luka. EGC : Jakarta.

[12] Muralidhar A, KS Babu, TR Sankar, P Reddana, J Latha. 2013. Wound Healing Activity of Flavonoid Fraction Isolated from the Stem Bark of Butea monosperma (Lem) in Albino Wistar Rats. European Journal of Experimental Biology.3(6).1-6.

[13] Khairany,Noorritha., Idiawati, Nora., Wibowo,Muhamad Agus., 2015, Analisis Sifat Fisik dan Kimia Gel Ekstrak Etanol Daun Talas (Colocasia esculenta (L.) Schott), JKK., 4(2) 81-88

[14] Rukmana Rahmad dan Yudi rachman Herdi. 2015. Untung berlipat dari budidaya talas. Lyli Publisher. Yogyakarta.

[15] Sangtam TL, NS Jamir, CR Deb, S Jamir. 2012. A Study on the Medicinal Plants Used by the Sangtam Naga Tribein Kiphire District, Nagaland, India. International Journal of Ayurvedic and Herbal Medicine.2(2).267-275.

[16] Sedjati, Sri., Yudiati, Ervia., Suryono. 2012. Profil Pigmen Polar dan Non Polar Mikroalga Laut Spirulina sp. dan Potensinya Sebagai Pewarna Alami.I/mu Kelautan Vol.17 (3) 176-181 